\title{
Review
}

\section{Mitochondrial implication in apoptosis. Towards an endosymbiont hypothesis of apoptosis evolution}

\author{
Guido Kroemer \\ ${ }^{1}$ Centre National de la Recherche Scientifique-UPR420, 19 rue Guy Môquet, \\ B.P.8, F-94801 Villejuif, France \\ 2 corresponding author: Dr. Guido Kroemer, 19 rue Guy Môquet, B.P. 8, F-94801 \\ Villejuif, France; tel: 33-1-49 5835 13; fax: 33-1-49 583509
}

Received 27.11.96; revised 18.3.97; accepted 1.4.97

Edited by P. Nicotera

\begin{abstract}
Recent evidence indicates that a profound alteration in mitochondrial function constitutes an obligatory early event of the apoptotic process. The molecular mechanism accounting for this alteration is mitochondrial permeability transition (PT). PT is both sufficient and necessary for apoptosis to occur. Experiments performed in cell-free systems of apoptosis demonstrate that mitochondria undergoing PT release protease activators that can trigger nuclear manifestations of apoptotis. Bcl-2 and its homologs are endogenous regulators of PT. It appears that some types of necrosis, those inhibited by $\mathrm{Bcl}-2$, involve PT. If PT is a rate-limiting event of both apoptosis and necrosis, then downstream events including caspase activation and the bioenergetic consequences of PT must determine the choice between both modes of cell death. PT without caspase activation would cause necrosis. These findings have important implications for the comprehension of the apoptotic process, for the dichotomy between apoptosis and necrosis, and for the phylogeny of programmed cell death. Apoptosis may have evolved together with the endosymbiotic incorporation of aerobic bacteria (the precursors of mitochondria) into ancestral unicellular eukaryotes.
\end{abstract}

Keywords: mitochondrial transmembrane potential, permeability transition, programmed cell death, proteases

\begin{abstract}
Abbreviations: AIF, apoptosis-inducing factor; ANT, adenine nucleotide translocator; DEX, dexamethasone; $\Delta \Psi_{\mathrm{m}}$, mitochondrial inner transmembrane potential; $\mathrm{mCICCP}$, carbonyl cyanide m-chlorophenlhydrazone; NGF, nerve cell growth factor; PBR, peripheral benzodiazepine receptor; PT, permeability transition; ROS, reactive oxygen species; TNF, tumor necrosis factor; VDAC, voltage-dependent anion channel
\end{abstract}

\section{Introduction}

Hundreds of different regimes induce apoptosis. In mammalian cells, such apoptotis-triggering stimuli include numerous toxins, suboptimal culture conditions, interventions on second messenger systems, and litigation of certain receptors (Fas/ APO-1/CD95, TGF-R, TNF-R, etc.) or, in the case of obligate growth factor receptor, the absence of receptor occupancy (Barr and Tomei, 1994; Kroemer, 1995; Kroemer et al, 1995; Thompson, 1995; Wertz and Hanley, 1996). In spite of the striking heterogeneity of apoptosis induction pathways, some characteristics of the apoptotic process are near-to-constant and do not depend on the induction protocol. This applies to certain nuclear features of apoptosis such as chromatin condensation and DNA fragmentation and extends to certain plasma membrane alterations (exposure of phosphatidylserine residues on the outer leaflet), as well as cytoplasmic changes (cell shrinkage, hyperproduction of reactive oxygen species, activation of certain proteases) (Cohen, 1991; Kroemer, 1995; Kroemer et al, 1995; Thompson, 1995). By consequence, a common pathway of apoptosis is likely to exist. The recent discovery that programmed cell death (PCD) may be induced in anucleate cells (cytoplasts) (Jacobson et al, 1994; Schulze-Osthoff et al, 1994; Nakajima et al, 1995) has led to the postulation of a cytoplasmic (non-nuclear) effector or 'central executioner' that would participate in life/ death decision making and would be influenced by endogenous control mechanisms (Jacobson et al, 1994; Oltvai and Korsmeyer, 1994; Henkart, 1995; Martin and Green, 1995). Once triggered, the central executioner would coordinate the different manifestations of the degradation phase of apoptosis, beyond the point-of-no-return of the apoptotic cascade.

The present review will summarize compelling evidence obtained by our laboratory, indicating that mitochondria play a major role in the apoptotic effector phase. In particular, I will examine the question of whether mitochondrial alterations associated with apoptotis may constitute the central executioner of cell death. Moreover, I will discuss the evolutionary implications of mitochondrial death control.

\section{The central executioner of apoptosis: a heptalog of minimum requirements}

Based on the current knowledge of apoptosis, as well as on theoretical considerations, the following seven criteria should be fulfilled by the hypothetical central executioner:

\section{Chronological criterion}

The central executioner should become activated during the effector stage of apoptosis, at the point-of-no-return, before the manifestations of the apoptotic degradation phase (nuclear changes, phosphatidylserine exposure, massive alterations of cellular redox potentials, advanced proteolysis of vital proteins etc.) become manifest. 


\section{Functional criterion}

The central executioner should consitute an essential feature of the apoptotic process. In other terms, it should be undissociable from naturally occurring apoptosis. In addition, it should be sufficient and necessary for apoptosis to occur.

\section{Criterion of convergence}

The central executioner should be triggered by many different apoptosis induction protocols, independently from the proapoptotic trigger-receptor-mediated signals or damagethus allowing for the convergence of different stimulusdependent signal transduction pathways into one single pathway.

\section{Criterion of coordination}

The central executioner should be capable of coordinating the different manifestations of apoptosis at the levels of the nucleus, the cytoplasm, and the plasma membrane. These alterations always become apparent in a near-to-simultaneous fashion in natural apoptosis, yet can be dissociated among each other. Thus, anucleate cells manifest the cytoplasmic and plasma membrane features of apoptosis (Jacobson et al, 1994; Schulze-Osthoff et al, 1994; Nakajima et al, 1995), and prevention of certain cytoplasmic features (e.g. hypergeneration of reactive oxygen species) does not suppress nuclear apoptosis (Hug et al, 1994; Jacobson and Raff, 1995; Shimizu et al, 1995). The fact that certain downstream events of apoptosis can be dissociated from each other, yet occur together in most experimental setups, suggests that they are coordinated by a hierarchically superior event, namely the central executioner.

\section{Criterion of ubiquity}

All cell types can be driven to undergo apoptosis, even in the presence of protein synthesis inhibitors (Ishizaki et al, 1995; Weil et al, 1996). This indicates that mammalian cells constitutively possess all the protein and non-protein structures necessary for apoptosis, including those forming the central executioner.

\section{Criterion of vitality}

All cells, even cancer cells and transformed cell lines maintained in auxotrophic conditions, can be driven into apoptosis, provided that sufficiently drastic induction protocols are applied (Ishizaki et al, 1995; Weil et al, 1996). This implies that the apoptotic machinery including the central executioner must contain major structural elements that are essential for cell survival. (If not, cells that are completely resistant to apoptosis would be generated by mutation). The central executioner (or the compounds that compose it) must have some function(s) that is/are essential for normal cell survival.

\section{Criterion of the switch}

Cells either survive or undergo apoptosis. There is no halfway intermediate. Therefore, the central executioner should function as a switch that is either off or on. In most biological system such switches are generated by positive feedback loops (Ptashne et al, 1980; Scott and O'Farrel, 1986). In other words, some of the consequences that result from triggering of the executioner should themselves stimulate the executioner. Such a self-amplification pathway would constitute the simplest fashion to make the executioner react as an all-ornothing device (Figure 1)

\section{Mitochondrial permeability transition as a critical coordinating step of apoptosis: a few hard facts}

We (Castedo et al, 1995; Zamzami et al, 1995a;b; 1996a,b; Castedo et al, 1996; Macho et al, 1996; Marchetti et al, 1996a,b,c; 1997; Susin et al, 1996a; Decaudin et al, 1997) and others (Vayssière et al, 1994; Cossarizza et al, 1995; Petit et al, 1995; Krippner et al, 1996; Liu et al, 1996; Murphy et al, 1996; Polla et al, 1996; Kluck et al, 1997; Yang et al, 1997) have recently obtained evidence indicating that mitochondrial structure and function are subject to profound

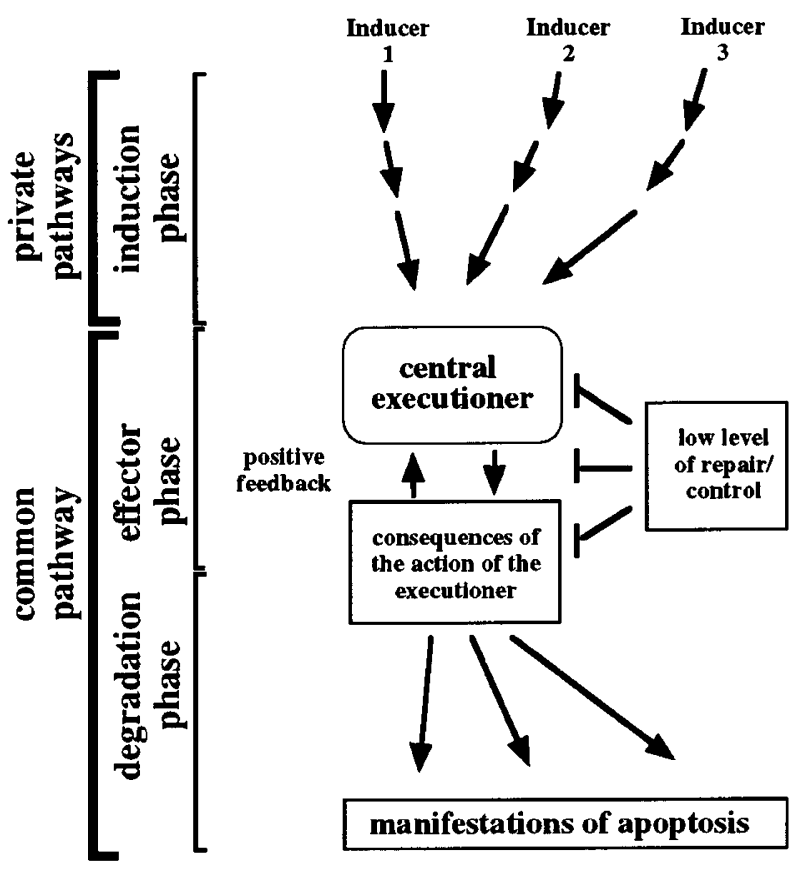

Figure 1 Schematic view of an apoptotic switch. Once induction of the central executioner is beyond the level that can be counteracted by control or repair mechanisms, the central executioner triggers one or several metabolic pathways that themselves activate the central executioner, thus engaging in a positive feedback loop. This hypothetical mechanism would explain why the central executioner would be either switched on or off instead of being activated in a gradual fashion. In addition, the diagram shows that several independent (private) pathways triggered during the apoptosis initiation phase can activate the central executioner which would constitute the bottle neck of the apoptosis process. The executioner would also be responsible for the coordination of the processes participating in the apoptotic degradation phase, beyond the point-of-no-return. 

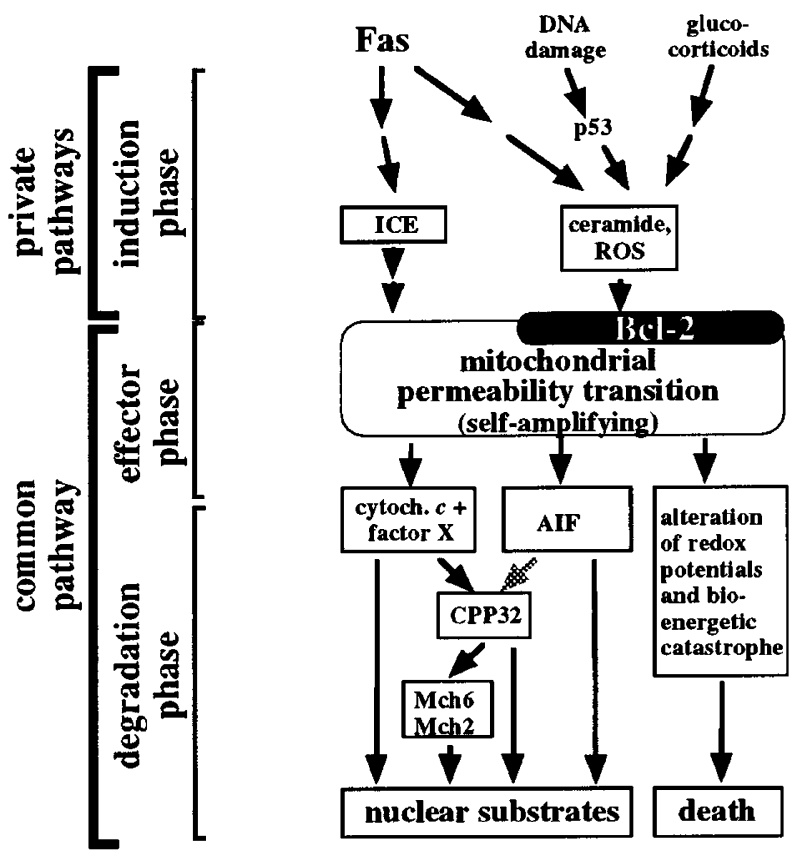

Figure 2 The apoptotic cascade. Different apoptosis-triggering pathways employ distinct signal transduction pathways that will culminate in the induction of permeability transition (PT). PT can be induced either in a Bcl-2regulated or in a $\mathrm{Bcl}-2$-independent fashion. Upon permeability transition, apoptogenic factors are released from the mitochondrial intermembrane space and leak into the cytosol. At least two such factors have been characterized: (i) cytochrome $c$ (which requires unknown cytosolic factors to activate CPP32 and to induce nuclear apoptosis) and (ii) AIF which suffices to induce nuclear apoptosis in vitro. Different proteases from the CPP32/Ced-3 family can participate in the apoptotic degradation phase downstream of PT. In addition, PT causes major changes in cellular redox potentials (depletion of nonoxidized glutathione, hyperproduction of superoxide anion), energy metabolism (depletion of $\mathrm{NAD}(\mathrm{P}) \mathrm{H}_{2}$ and $\mathrm{ATP}$ ), and ion compartmentalization. alterations early during the apoptotic process (reviewed by Kroemer et al, 1995, 1997; Marchetti et al, 1996d; Petit et al, 1996; Susin et al, 1996b) (Figure 2). These alterations can be attributed to mitochondrial permeability transition (PT), a well studied phenomenon that is known since the fifties (reviewed by Zoratti and Szabò, 1995; Bernardi and Petronilli, 1996). PT is a process whose physiological function has remained elusive for decades. It consists in the opening of a pore, the PT pore or mitochondrial megachannel, that can be formed by apposition of transmembrane proteins from the two mitochondrial membranes in inner/outer membrane contact sites. The exact composititon of the PT pore complex is elusive. At present, it is not known which proteins participate in its formation and which are rather involved in its regulation. One of the key elements of the PT pores is probably the adenine nucleotide translocator (ANT) (Brustovetsky and Klingenberg, 1996). The ANT has been shown to interact with outer membrane proteins including the peripheral benzodiazepin receptor (PBR, also called: endozepin receptor or receptor for the CoA-binding protein) and porin (alternative name: voltagedependent anion channel, VDAC) (McEnergy et al, 1992; Kinnally et al, 1993). In addition, soluble proteins contained in the cytosol (hexokinase), intermembrane space (creatine kinase) and in the matrix (cyclophilin D) may participate in the formation of a dynamic multiprotein ensemble that participates in the control of the PT pore (Beutner et al, 1996; Nicolli et al, 1996) (Table 1). Some data suggest that the TIM (translocase of the inner membrane) and TOM (translocase of the outer membrane) complexes (which are involved in protein import) might also participate in the formation/regulation of the PT pore (Kinnally et al, 1996; Sokolove and Kinnally, 1996). It has also proposed that interactions between mitochondria and the cytoskeleton may participate in PT control (Evtodienki et al, 1996).

Table 1 Molecules in the PT pore complex as targets for pharmacological apoptosis modulation

\begin{tabular}{|c|c|c|c|}
\hline Molecule (topology) & Normal function & Ligands and role in PT & Reference \\
\hline $\begin{array}{l}\text { Adenine nucleotide } \\
\text { translocator (ANT) } \\
\text { (inner membrane) }\end{array}$ & ATP/ADP antiport & $\begin{array}{l}\text { Bongkrekic acid: favors m-state } \\
\text { and inhibits PT } \\
\text { Atractyiloside: favors c-state } \\
\text { and induces PT }\end{array}$ & $\begin{array}{l}\text { Klingenberg, } 1980 \\
\text { Brustovetsky et al, } 1996 \\
\text { Klingenberg, 1980 } \\
\text { Brustovetsky et al, } 1996\end{array}$ \\
\hline $\begin{array}{l}\text { Peripheral benzodiazepin } \\
\text { receptor (PBR) } \\
\text { (outer membrane) }\end{array}$ & $\begin{array}{l}\text { Receptor for endozepin } \\
\text { (=CoA-binding protein) }\end{array}$ & Protoporphyrin IX: induces PT & Pastorino et al, 1994 \\
\hline Porin (outer membrane) & $\begin{array}{l}\text { Voltage-dependent anion } \\
\text { channel }\end{array}$ & & Beutner et al, 1996 \\
\hline $\begin{array}{l}\text { Cyclophilin D } \\
\text { (matrix) }\end{array}$ & $\begin{array}{l}\text { Peptidyl prolyl isomerase } \\
\text { (chaperone function) }\end{array}$ & $\begin{array}{l}\text { Cyclosporine A: inhibits interaction } \\
\text { with inner membrane } \\
\text { N-methyl-Val-4-cyclosporine A } \\
\text { (non-immunosuppressive) }\end{array}$ & Nicolli et al, 1996 \\
\hline $\begin{array}{l}\text { Hexokinase } \\
\text { (cytosol) }\end{array}$ & $\begin{array}{l}\text { Phosphorylates hexa- } \\
\text { saccharides (mainly glucose) } \\
\text { while hydrolysing ATP }\end{array}$ & Facilitates or regulates $\mathrm{PT}$ & Beutner et al, 1996 \\
\hline $\begin{array}{l}\text { Creatine kinase } \\
\quad \text { (intermembrane) }\end{array}$ & $\begin{array}{l}\text { Transfers phosphate from } \\
\text { creatinephosphate to ADP or } \\
\text { from ATP to creatine }\end{array}$ & Inhibits PT & Beutner et al, 1996 \\
\hline Matrix thiols & $\begin{array}{l}\text { Thiol sensor for redox } \\
\text { potentials }\end{array}$ & $\begin{array}{l}\text { Thiol oxidation and disulfide bridge } \\
\text { formation favor PT }\end{array}$ & Costantini et al, 1996 \\
\hline $\mathrm{Ca}^{2+}$ sensitive sites & Sensor for divalent cations & Calcium favors PT & $\begin{array}{l}\text { Zoratti and Szabò, } 1995 \\
\text { Bernardi and Petronilli, } 1996\end{array}$ \\
\hline
\end{tabular}


Numerous physiological effectors determine whether the PT pore complex adopts its open conformation. Such effectors include divalent cations (calcium, magnesium) (Szabó et al, 1992), protons (Bernardi et al, 1992), the concentration of ATP and ADP, the $\mathrm{NAD}(\mathrm{P}) \mathrm{H}_{2} / \mathrm{NAD}(\mathrm{P})$ ratio, thiol redoxidation (Constantini et al, 1996), amphipathic peptides (Pfeiffer et al, 1995), fatty acids (Zoratti and Szabó, 1995), and perhaps calpain-like proteases (Aguilar et al, 1996). PT entails the free diffusion of solutes $<1500 \mathrm{Da}$ across the inner mitochondrial membrane, thus disrupting ipso facto the mitochondrial transmembrane potential $\left(\Delta \Psi_{\mathrm{m}}\right)$, which is essentially a proton gradient (Zoratti and Szabò, 1995). In addition, PT is followed by the efflux of soluble proteins from the matrix and intermembrane space (Igbavboa et al, 1989; Fiskum and Murphy, 1996; Susin et al, 1996a).

Here, I will briefly recapitulate current evidence implicating PT in apoptosis. These data have been extensively reviewed in several papers (Kroemer et al, 1995; 1997; Marchetti et al, 1996d; Petit et al, 1996; Susin et al, 1996b), which may be consulted for further details.

\section{PT is a constant, early feature of apoptosis}

In all cell types and in response to all apoptosis induction protocols tested thus far, cells manifest a collapse of the $\Delta \Psi_{\mathrm{m}}$ that precedes nuclear apoptosis (Table 2). We have noted that, in contrast to one report (Yang et al, 1997), apoptosis induced by staurosporine, ceramide and Fas crosslinking, does involve a $\Delta \Psi_{\mathrm{m}}$ disruption that precedes activation of CPP32-like caspases (Susin et al, 1996a and unpublished observations). PT and subsequent nuclear apoptosis are undissociable in the sense that blockade of apoptosisinducing pathways also prevents the pre-apoptotic $\Delta \Psi_{\mathrm{m}}$ disruption. We have tested specific inhibitors of PT on cells that are losing their $\Delta \Psi_{\mathrm{m}}$ to show that the mechanism of the $\Delta \Psi_{\mathrm{m}}$ collapse involves PT. Thus, bongkrekic acid (a ligand of the ANT), cyclosporin A (a ligand of matrix cylophilin D) and chloromethyl-X-rosamine (which acts on matrix thiols) can prevent the pre-apoptotic $\Delta \Psi_{\mathrm{m}}$ loss in appropriate experimental conditions (Zamzami et al, 1995a; 1996a). It should be noted that cyclosporin $A$ is only a transient $(<1 \mathrm{~h}$ ) inhibitor of PT (Nicolli et al, 1996), whereas bongkrekic acid and chloromethyl-X-rosamine are long-term PT inhibitors (Zamzami et al, 1995a; 1996a; Marchetti et al 1996a; 1997).

\section{PT is sufficient and necessary for apoptosis}

Triggering of PT with agents specifically acting on mitochondrial structures suffices to induce apoptosis (Table 2). This applies to drugs such as protoporphyrin IX (Marchetti et al, 1996a,b), which acts on the peripheral (mitochondrial) benzodiazepin receptor (PBR) to induce PT (Pastorino et al, 1994), or protonophores, which act on the inner mitochondrial membrane to disrupt the $\Delta \Psi_{\mathrm{m}}$ (Zamzami et al, 1996b). More importantly, specific inhibitors of PT such as bongkrekic acid (Marchetti et al, 1996a;b; Zamzami et al, 1996b) and chloromethyl-X-rosamine (Marchetti et al, 1997) prevent PT and subsequent nuclear apoptosis in a number of different models (Table 2).

\section{PT liberates apoptogenic factors from mitochondria}

Isolated mitochondria driven to undergo PT in vitro, liberate at least two potentially apoptogenic factors: (i) a $\sim 50 \mathrm{kDa}$ protein that we termed 'apoptosis inducing factor' (AIF) and which suffices to provoke nuclear apoptosis (chromatin condensation+oligonucleosomal DNA fragmentation) even in the absence of additional factors (Susin et al, 1996), and (ii) cytochrome $c$ (Fiskum and Murphy, 1996), which, together with unknown cytoplasmic factors, can trigger nuclear apoptosis in vitro (Liu et al, 1996). AIF is likely to be a protease since it can be inhibited by $N$-benzyloxycarbonylVal-Ala-Asp.fluoromethylketone (z-VAD.fmk) (Susin et al, 1996a), an inhibitor of 'ICE-like' proteases which prevents apoptosis in numerous experimental models (Fearnhead et al, 1995; Zhu et al, 1995; Cain et al, 1996; Jacobson et al, 1996; Slee et al, 1996). Cytochrome $c$ cooperates with one or several yet to be characterized cytoplasmic factor(s) to activate the protease CPP32/YAMA/Apopain (Liu et al, 1996), one of the signature enzymes of apoptosis (Nicholson et al, 1995). It remains elusive whether AIF and cytochrome $c$ extrude via the PT pore or whether their liberation involves other structures in the outer mitochondrial membrane or a rupture of mitochondrial membranes.

\section{$\mathrm{Bcl}-2$ functions as an endogenous inhibitor of PT}

The predominant intracellular localization of $\mathrm{Bcl}-2$ and its homologs is the outer mitochondrial membrane (Krajewski et al, 1993; Gonzalez-Garcia et al, 1994). Genetic manipulations has shown that, at least in certain experimental conditions, $\mathrm{Bcl}-2$ must be specifically located in mitochondrial rather than in other cellular membranes to prevent apoptosis (Tanaka et al, 1993; Nguyen et al, 1994; Zhu et al, 1996). In cell-free systems of apoptosis, Bcl-2 also must be present in mitochondria rather than in the nuclear envelope to inhibit apoptosis (Newmeyer et al, 1994; Susin et al, 1996a; Kluck et al, 1997; Yang et al, 1997). Bcl-2 prevents the PT-mediated $\Delta \Psi_{\mathrm{m}}$ disruption in cells (Zamzami et al, 1995a; Castedo et al, 1996; Susin et al, 1996a; Decaudin et al, 1997), cytoplasts (anucleate cells) (Decaudin et al, 1997), and isolated mitochondria (Marchetti et al, 1996b; Susin et al, 1996; Zamzami et al, 1996b). Bcl-2 prevents the PT-dependent liberation of AIF from mitochondria, yet has no effect on the formation or action of AIF (Susin et al, 1996a). Since pharmacological inhibition of PT also prevents apoptosis (Marchetti et al, 1996a,b; 1997; Zamzami et al, 1996b), it thus appears plausible that $\mathrm{Bcl}-2$ suppresses cell death via controlling PT. Recently, Bcl-2 has been shown to prevent the mitochondrial release of cytochrome $c$ (Kluck et al, 1997; Yang et al, 1997). It is a matter of debate whether this is a primary effect of $\mathrm{Bcl}-2$ or whether it rather results from the Bcl-2-mediated inhibition of PT. Our unpublished results, as well as those obtained by Murphy and co-workers (Fiskum and Murphy, 1996), suggest that cytochrome $c$ release is a result rather than a trigger of $\mathrm{PT}$. This would suggest that $\mathrm{Bcl}-2$ acts at the level of PT or immediately upstream of PT. Irrespective of these details, it must be expected that 
Table 2 Apoptosis-inducing regimes which induce a $\Delta \Psi_{\mathrm{m}}$ disruption preceding nuclear DNA fragmentation and their inhibition

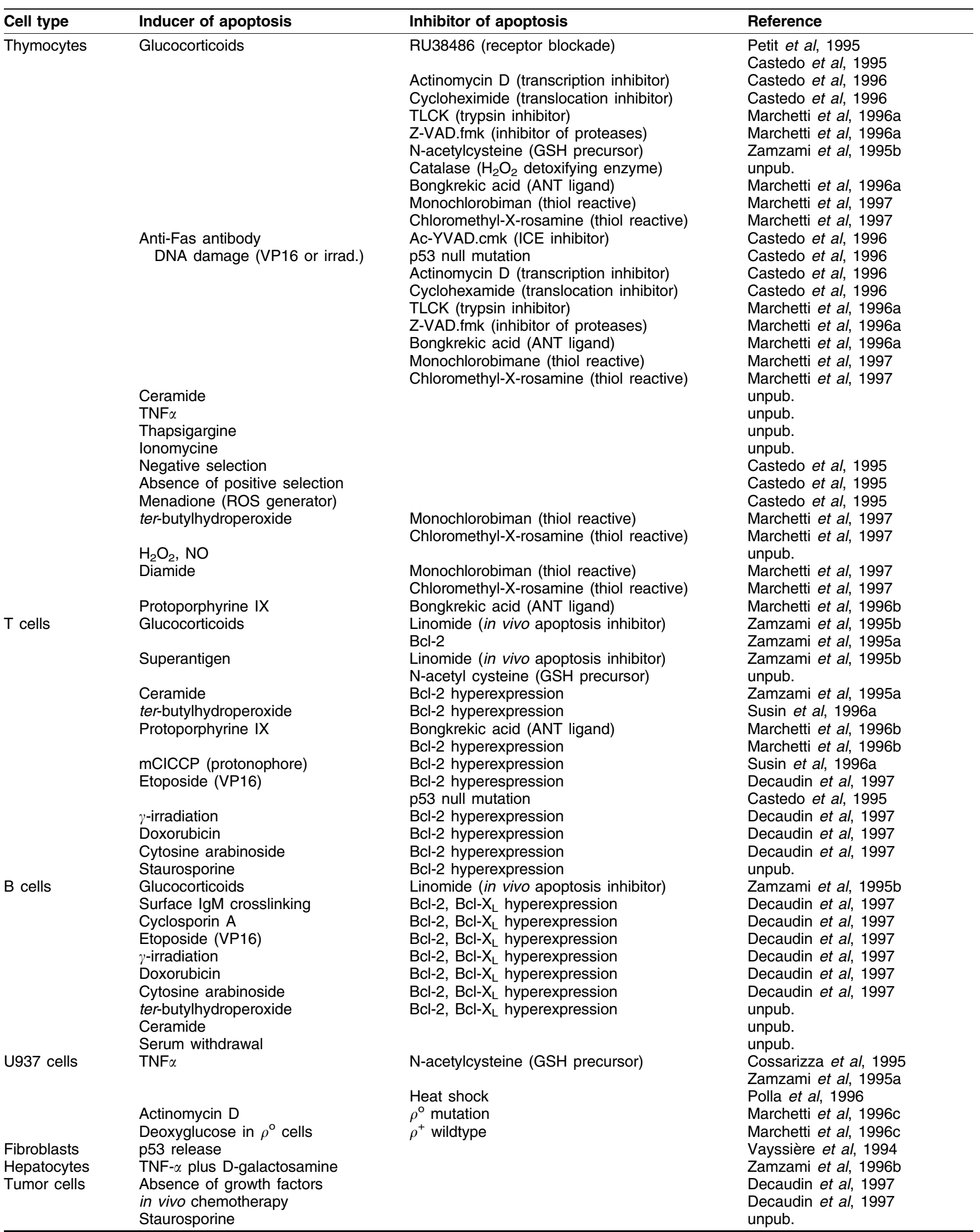


Table 2 continued

\begin{tabular}{|c|c|c|c|}
\hline Cell type & Inducer of apoptosis & Inhibitor of apoptosis & Reference \\
\hline Neurons & $\begin{array}{l}\text { NGF withdrawal } \\
\text { Glutamate }\end{array}$ & $\begin{array}{l}\text { NGFreaddition } \\
\text { Cyclosporin A } \\
\text { NMDA receptor blockade } \\
\text { Absence of extracellular calcium } \\
\text { Inhibitor of mit. } \mathrm{Na}^{+} / \mathrm{Ca}^{2+} \text { exchanger } \\
\text { Bcl-2 hyperexpression }\end{array}$ & $\begin{array}{l}\text { Deckwerth et al, } 1993 \\
\text { Ankarcrona et al, } 1995 \\
\text { Schinder et al, } 1996 \\
\text { White and Reynolds et al, } 1996 \\
\text { White and Reynolds et al, } 1996 \\
\text { White and Reynolds et al, } 1996 \\
\text { White and Reynolds et al, } 1996 \\
\text { Shimizu et al, } 1996\end{array}$ \\
\hline
\end{tabular}

Bax, an antagonist of Bcl-2, should induce $\Delta \Psi_{\mathrm{m}}$ disruption. Indeed, transfection-enforced hyperexpression of Bax has recently been shown to provoke a collapse of the $\Delta \Psi_{m}$ (Xiang et al, 1996).

\section{Mitochondrial permeability transition (PT): the central executioner of apoptosis?}

The data discussed above indicate that mitochondria are involved in apoptosis. However, does this imply that mitochondria events control the central executioner? Here, I will examine the possibility that mitochondrial PT might constitute (or form part of) the central executioner. Does PT meet the seven minimum requirements that the central executioner should fulfil?

\section{Chronological criterion}

PT-mediated $\Delta \Psi_{\mathrm{m}}$ disruption is indeed an early, pre-nuclear event of the apoptotic process (Castedo et al, 1995; 1996; Zamzami et al, 1995a,b; 1996a,b; Macho et al, 1996; Marchetti et al, 1996a,b,c; 1997; Susin et al, 1996a; Decaudin et al, 1997). Cells that have disrupted their $\Delta \Psi_{\mathrm{m}}$ are irreversibly committed to undergo death, even when the apoptosis-inducing trigger is withdrawn (Zamzami et al, 1995a). Thus, the $\Delta \Psi_{m}$ collapse marks the point-of-no-return of apoptosis, yet precedes all common signs of the apoptotic degradation phase: nuclear apoptosis, PS exposure on the membrane, and activation of CPP32-related caspases.

\section{Functional criterion}

PT appears indissociable from subsequent nuclear apoptosis. It is sufficient and necessary for nuclear apoptosis to occur. This notion is based on pharmacological evidence. Induction of PT causes apoptosis, and its inhibition prevents apoptosis (Marchetti et al, 1996a,b; 1997b; Zamzami et al., 1996b). In addition, the finding that $\mathrm{Bcl}-2$ and other apoptosis-inhibitory $\mathrm{Bcl}-2$ homologs such as Bcl-X prevent PT (Castedo et al, 1996; Susin et al, 1996a; Zamzami et al, 1996b; Decaudin et al, 1997) emphasizes the functional importance of PT in life/death decision making.

\section{Criterion of convergence}

PT is triggered by numerous physiological and aphysiological effectors, both in cells and in isolated mitochondria (Table 1).
Thus, it appears that numerous stress responses (increase in calcium, depletion in non-oxidized glutathione, ATP or $\mathrm{NAD}(\mathrm{P}) \mathrm{H}_{2}$ decrease, genotoxic stress, proteases etc.) can trigger $\mathrm{PT}$ in cells (Table 2), rendering $\mathrm{PT}$ an attractive candidate for a universal stress sensor. It appears that PT is not only activated by unphysiological stress responses. Rather, it is also triggered by signal transduction pathways activated upon ligation of receptors (glucocorticoid receptor, Fas/APO-1/CD95, TNF-R etc.) as well as ceramide, a second messenger involved in several apoptotic pathways. At present, it is not known which are the final molecular effectors responsible for the induction of apoptotic PT when apoptosis is receptor-induced.

\section{Criterion of coordination}

PT entails a number of profound alterations in cell metabolism, all of which are constant features of apoptosis. In addition to provoking nuclear apoptosis (Marchetti et al, 1996b; Susin et al, 1996a; Zamzami et al, 1996b), PT causes an increase in superoxide generation on the uncoupled respiratory chain (Zamzami et al, 1995a), thereby profoundly affecting cellular redox potentials. Thus, PT entails the depletion of non-oxidized glutathione (Marchetti et al, 1996a; Macho et al, 1997) and the irreversible superoxide mediated oxidation of cardiolipins and other membrane lipids (Zamzami et al, 1995a,b). This observation, together with the obvious effects of PT on energy metabolism, indicates that PT triggers several pathways each of which would be lethal by itself. Pharmacological inhibition of PT prevents all manifestations of apoptosis, at the levels of the nucleus, the plasma membrane, and the cytoplasma (Marchetti et al, 1996a), emphasizing that PT can indeed function as a central coordinating event.

\section{Criterion of ubiquity}

Essential components of the PT such as the ANT and porin are found in all cell types. These molecules are phylogenetically old and relatively conserved. Indeed, molecules such as the ANT (which exchanges matrix ATP for cellular ADP) are essential for oxidative phosphorylation and thus must be expressed in all living cells (Klingenberg, 1980). For obvious reasons, the apoptogenic factor cytochrome $c$, which participates in the respiratory chain, also must be present in all respiring cells. AlF-like activity has also been detected in many different tissues (Susin et al, 1996a), suggesting that it may be ubiquitous. 


\section{Criterion of vitality}

Although some if not all PT pore components are essential for cellular metabolisms and although PT is phylogenetically old-it has been described in yeast mitochondria (Szabo et al, 1995) - it is not clear whether PT might have any physiological function not related to apoptosis. Thus, this issue has to await future clarification. According to Brdiczka and coworkers, the PT pore might be important for the handling of ATP and metabolic control (Beutner et al, 1996). This idea is based on the observation that many of the proteins involved in formation/regulation of the PT pore specifically interact with ATP: porin (which regulates ATP flux through the outer membrane; Rostovtseva and Colombini, 1996), hexokinase, and obviously the ANT. Bernardi and coworkers (Bernardi and Petronilli, 1996) propose an alternative physiological role for PT. Short spikes of PT may be involved in the periodic outflow of calcium from the mitochondrial matrix and this would be necessary to avoid excessive calcium accumulation in mitochondria. Another hypothesis is brought forward by Kinnally and colleagues. These authors suggest that the PT pore might be identical with a mitochondrial multiple conductance channel modulated by peptides responsible for targeting mitochondrial precursor proteins (Kinnally et al, 1996; Sokolove and Kinnally, 1996). This would imply that the PT pore participates in the import of nuclear gene products into mitochondria. If one of these hypotheses was confirmed, PT would be essential for normal mitochondrial function.

\section{Criterion of the switch}

As summarized in Table 3, many of the consequences of PT themselves trigger PT. Thus, $\Delta \Psi_{\mathrm{m}}$ disruption, increases in cytosolic free $\mathrm{Ca}^{2+}$ concentrations, oxidative changes in the redox potential, and protease activation result from PT at the time that they induce PT. This feature of self-amplification renders $\mathrm{PT}$ an attractive candidate to constitute the (or a) death switch.

In synthesis, it appears that PT could fulfil most if not all criteria of the central executioner. At this point, it should be noted that different proteases, mainly those from the ICE family, have also been suggested to form part of the executioner (Martin and Green, 1995; Henkart et al, 1996). Future investigation will have to clarify the exact relationship between PT and protease cascades, as well as their relative contribution to the central executioner of apoptosis.

\section{The necrosis/apoptosis paradox: resolved?}

Although apoptosis has been initially defined by confronting it with necrosis (Kerr et al, 1972), several observations question the paradigmatic opposition between these two types of cell death. As a matter of fact, several pathologies which were previously thought to involve primary necrosis, are now described to involve apoptosis: apoplexy (Martinou et al, 1994), myocardial infarction (Itoh et al, 1995), kainate-induced neural cell death (Simonian et al, 1996), and ischemia/ reperfusion damage (Fliss and Gattinger, 1996; Sasaki et al, 1996). More importantly, hyperexpression of the apoptosisinhibitory oncoprotein $\mathrm{Bcl}-2$ has been shown to inhibit necrotic cell death in a number of models: kainate-induced neuronal necrosis (Kane et al, 1993), occlusion of the midbrain artery (Martinou et al, 1994), absence of oxygen (Shimizu et al, 1995), and chemical hypoxia (Shimizu et al, 1996). PC12 pheochromocytoma cells treated with rotenone or cyanide die from necrosis after having disrupted their $\Delta \Psi_{\mathrm{m}}$. Transfectionenforced hyperexpression of Bcl-2 prevents both the $\Delta \Psi_{\mathrm{m}}$ disruption and the subsequent necrosis (Shimizu et al, 1996). Pharmacological induction of PT entails hepatocyte necrosis (Pastorino et al, 1994; Trost and Lemasters, 1996). This suggests that, at least in some instances, PT constitutes a molecular event that is also involved in necrosis.

The above findings may be integrated into the following hypothesis (Figure 3). When PT is induced in a massive, rapid fashion heavily compromising the ATP supply, necrosis (that is primary disruption of the plasma membrane) occurs before apoptogenic proteases are activated and can act on nuclear and cytoplasmic substrates. In contrast, induction of PT in a more smooth, protracted fashion, would allow for the activation and action of specific proteases (AIF, CPP32 and other downstream proteases) before ATP depletion and other consequences of PT such as enhanced superoxide anion generation cause cell death. In other terms, the intensity of

Table 3 Self-amplifying features of mitochondrial permeability transition (PT)

\begin{tabular}{|c|c|}
\hline Inducer of PT & Consequence of PT \\
\hline$\Delta \Psi_{\mathrm{m}}$ reduction facilitates PT (Bernardi, 1992) & PT causes $\Delta \Psi_{\mathrm{m}}$ disruption (Zoratti and Szabò, 1995) \\
\hline $\begin{array}{l}\text { Calcium causes PT (Szabò et al, 1992; } \\
\text { Zoratti and Szabò, 1995) }\end{array}$ & $\begin{array}{l}\text { PT causes outflow of matrix calcium and ATP } \\
\text { depletion, thereby disrupting calcium } \\
\text { homeostaia (Zoratti and Szabò, 1995) }\end{array}$ \\
\hline $\begin{array}{l}\text { Thiol oxidation of matrix proteins induces } \\
\text { PT (Costantini et al, 1996) }\end{array}$ & $\begin{array}{l}\text { PT causes depletion of non-oxidized glutathione, } \\
\text { thereby favoring protein thiol oxidation (Zoratti and } \\
\text { Szabò, } 1995\end{array}$ \\
\hline $\begin{array}{l}\text { Oxidation of } \mathrm{NAD}(\mathrm{P}) \mathrm{H}_{2} \text { favors } \mathrm{PT} \\
\quad \text { (Costantini et al, 1996) }\end{array}$ & $\begin{array}{l}\text { PT results in } \mathrm{NAD}(\mathrm{P}) \mathrm{H}_{2} \text { oxidation } \\
\text { (Petit et al, 1995) }\end{array}$ \\
\hline $\begin{array}{l}\text { Reactive oxygen species induce PT } \\
\text { (Zoratti and Szabò, 1995) }\end{array}$ & $\begin{array}{l}\text { PT causes hypergeneration of superoxide anion } \\
\text { on the uncoupled respiratory chain (Vayssière et al, 1994; } \\
\text { Zamzami et al, 1995) }\end{array}$ \\
\hline Proteases can cause PT (Marchetti et al, 1996a) & $\begin{array}{l}\text { PT results in protease activation (Lui et al, 1996; } \\
\text { Susin et al, 1996a) }\end{array}$ \\
\hline
\end{tabular}




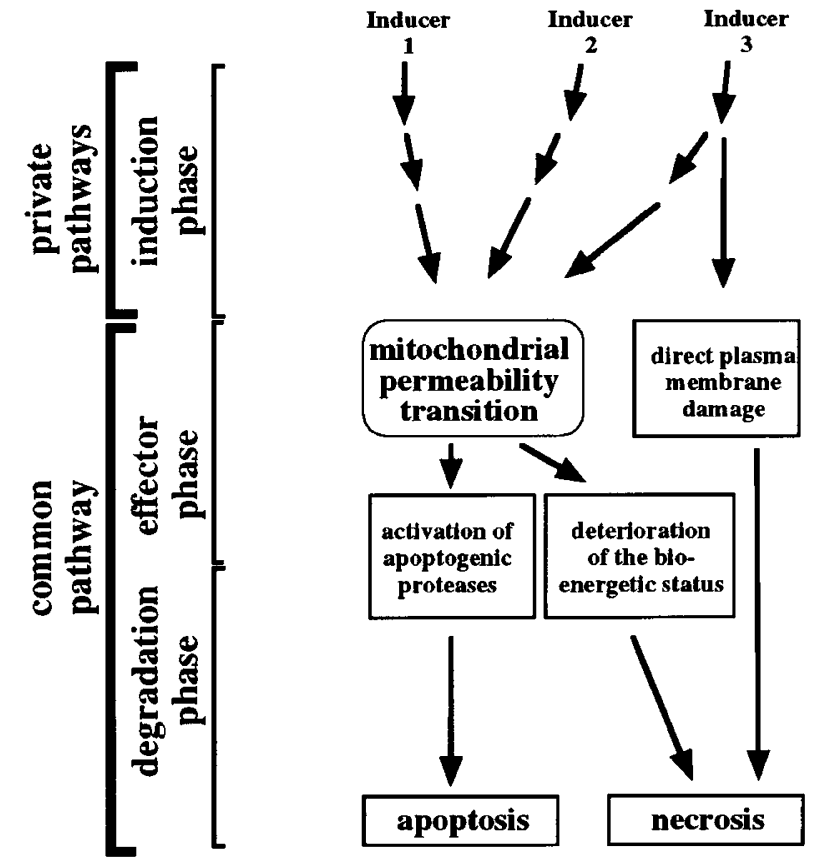

Figure 3 Hypothetical model of the dichotomy between apoptosis and necrosis. Massive induction of PT with subsequent rapid depletion of ATP causes primary necrosis, that is the disruption of plasma membrane integrity before apoptogenic proteases come into action. In contrast, a more subtle induction of PT allows for the activation of proteases culminating in manifest nuclear apoptosis. In some instances, direct plasma membrane damage provokes fulminant necrosis without that $\mathrm{PT}$ would be required for cell death.

the PT-inducing stimulus would determine which among two major consequences of $\mathrm{PT}$ wins the race: a bioenergetic and redox catastrophe culminating in necrosis or the activation/ action of apoptogenic proteases. This scenario would be compatible with the finding that many drugs induce necrosis at high doses and apoptosis at lower ('subnecrotic') doses (Kroemer, 1995). It would also be compatible with the observation that modulation of ATP levels can shift the balance between apoptosis and necrosis to one or the other mode of cell death (see accompanying reviews by Nicotera and Leist, 1997; Tsujimoto, 1997). Finally, it would explain why cells in which the activation of most if not all caspases is inhibited by means of the inhibitor Z-VAD.fmk ( $N$-benzyloxycarbonyl-Val-Ala-Asp-fluromethylketone) undergo nonapoptotic (necrotic?) rather than apoptotic cell death when transfection-enforced hyperexpression of the Bcl-2 antagonists Bax or Bak causes disruption of mitochondrial function (Xiang et al, 1996; McCarthy et al, 1997).

\section{The evolutionary origin of death: premises of an endosymbiont hypothesis of apoptosis}

As discussed in the foregoing sections, mitochondrial PT appears to be the decisive mechanism of apoptosis. This may have major implications for the phylogeny of apoptosis. I will first expose the premises of my hypothesis regarding the evolutionary origin of apoptosis and then formulate my speculation.

\section{The endosymbiotic origin of mitochondria}

It is widely accepted that eukaryotic cells are descendants of primitive anaerobic organisms that survived, in a world that had become rich in oxygen, by engulfing aerobic bacteria - keeping them in symbiosis for the sake of their capacity to consume atmospheric oxygen and to produce ATP. Thus mitochondria would originate from Krebs-cycle-containing eubacteria (promitochondria) invading a fermentative anaerobe (Margulis, 1975). During eukaryotic evolution, then most of the genetic information contained in the pro-mitochondrial genome has been incorporated into the nuclear genome (Gray, 1989).

\section{Programmed cell death is phylogenetically old}

Apoptosis or apoptosis-like phenomena have been described for a number of unicellular eukaryotes, including Trypanosoma cruzi (Ameisen et al, 1995), Trypanosoma brucei rhodesiense (Welburn et al, 1996), Leishmania amazonensis (Moreira et al, 1996), Tetrahymena thermophila (Mpoke and Wolfe, 1996) and Euglena gracilis (Scheuerlein et al, 1995). Apoptosis-like phenomena are also found in fungi (Cornillon et al, 1994) and plants (Mittler and Lal, 1995; Greenberg, 1996; Jones and Dangl, 1996). Thus, apoptosis as such has not evolved during the invention of multicellularity, as has been generally assumed, but rather before. Although developmentally regulated (programmed) cell death is probably only instaured in multicellular organisms (Raff, 1994), it appears that the basic mechanisms of apoptosis are already found in unicellular organisms. Thus apoptosis may have evolved at the same time as did endosymbiosis.

\section{PT, some constituents of the PT pore and several apoptosis effector molecules are phylogenetically old}

PT-like phenomena have been described in Saccharamyces cerevisiae (Szabo et al, 1995). A few molecules contained in the PT pore complex are found in both prokaryotes and eukaryotes: cyclophilins and porins (Schulz, 1996). An analog of the PBR has been described in Rhodobacter capsulatus (Armstrong et al, 1989). The ANT gene is found in the nuclear genome of unicellular eukaryotes, plants, fungi and metazoans (Kuan and Saier, 1993; Walker and Runswick, 1993), and functionally analogs may be found in Rickettsia prowazekii (Krause et al, 1985; Carmeli and Lifshitz, 1989) as well as the internal membrane of certain bacteria such as Rhodobacter capsulatus (Carmeli and Lifshitz, 1989). However, the mitochondrial carrier family of transport proteins, to which the eukaryotic ANT belongs, has been suggested to arise shortly after the formation of the endosymbiotic relationship between the progenitor of the mitochondrion and that of eukaryotic cells (Walker and Runswick, 1993). Members of the $b c l-2$ gene family exhibit structural analogies with colicins (Muchmore et al, 1996), a family of bactericidal compounds elaborated by Escherichia coli (Stroud, 1995). Intriguingly, the $b c l-2$ homologue of $C$. elegans, ced-9, forms part of a polycistronic locus also containing cytochrome b540, which belongs to respiratory chain complex II (Hengartner and 
Horvitz, 1994). This may suggest that both genes have been transferred together from the pro-mitochondrial genome to the nucleus. Cytochrome $c$ is already contained in aerobic bacteria, and some mitochondrial and extramitochondrial proteases may well have a bacterial origin (Rawlings and Barrett, 1993). In conclusion, it appears possible that many of the constituents of the PT pore and several apoptogenic mitochondrial proteins were already present in the aerobic bacterium from which the mitochondrion evolved.

\section{Members of the Bcl-2 family act on an evolutionary conserved death pathway}

As mentioned above, members of the Bcl-2 family of apoptosis-regulatory proteins from animals have structural equivalents in bacteria. Importantly enough, certain products of the $\mathrm{Bcl}-2$ gene family are lethal across species barriers. Thus the Bcl-2 antagonist Bax (which is necessary for neuronal apoptosis to occur in mice; Knudson et al, 1995) kills Saccharomyces cerevisiae cells carrying functional mitochondria as well bacteria in which it is overexpressed (Sato et al, 1994; Greenhalf et al, 1996; Zha et al, 1996). To kill yeast cells, Bax must be targeted to mitochondria (Zha et al, 1996). Bcl-2 has also been shown to rescue mutant yeast strains with defects in superoxide dismutase from the lethal effects of growth under aerobic conditions (Kane et al, 1993). Moreover, it can prevent the lethal effect of Bax overexpression in yeast cells (Sato et al, 1994; Greenhalf et al, 1996; Zha et al, 1996). It may be important to note that yeast cells killed by Bax overexpression do not undergo oligonucleosomal DNA fragmentation nor present any signs of apoptotic morphology (chromatin condensation, membrane blebbing etc.). Thus, it appears that the $\mathrm{Bcl}-2 / \mathrm{Bax}$ regulation of cell death - at the level of mitochondria - is phylogenetically conserved between pluricellular animals and unicellular fungi, whereas nuclear apoptosis is not.

\section{Addiction modules}

One possibility to confer a selective replication advantage to bacterial plasmids consists in the generation of an 'addiction module' (Jensen and Gerdes, 1995; Naito et al, 1995; Yarmolinsky, 1995). If the plasmid encodes both a long-lived toxin and a short-lived antidote, then loss or
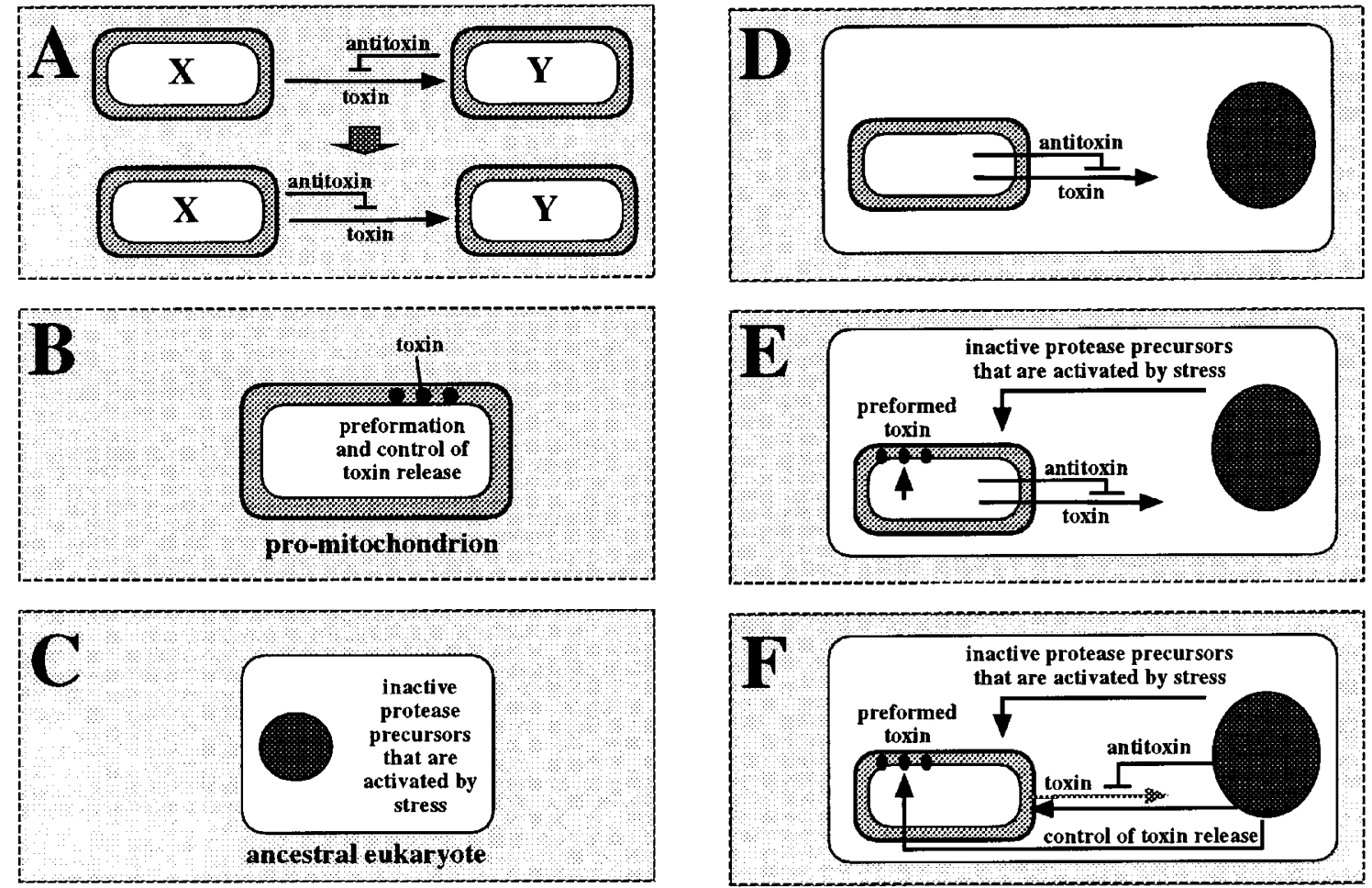

Figure 4 The endosymbiont hypothesis of apoptosis. (A) Generation of an addiction module in bacteria. A bacterium $\mathrm{X}$ generates a toxin for strain $\mathrm{Y}$, which in turn produces an antitoxin. The toxin-producing strain eventually acquires the genetic information for the antitoxin. (B) As an alternative, a bacterium produces toxins that are pre-formed, compartmentalized and only released in particular circumstances, e.g. after aggression/lysis by other organisms. (C) The ancestral eukaryote still lacking mitochondria possesses proteases or other enzymes with antibiotic activity that are activated upon stress (e.g. invasion by bacteria). (D) Addiction in endosymbiosis. The pro-mitochondrion which incorporates into the pro-eukaryote produces both a toxin and an antitoxin. Since the latter has a shorter half life than the former, elimination of the mitochondrion would be lethal for the eukaryotic host cell. (E) Same as D incorporating the possibilities demonstrated in B and C. The bacterium contains pre-formed toxins that are released upon lysis of the bacterium. In addition the host produces antibiotics that are either present as inactivated precursors or a compartmentalized (e.g. in lysosomes). Any damage or stress to the host would activate or liberate these antibiotics and thus cause bacterial death which in turn would cause liberation of toxins from the bacterium. (F) Due to the shuffling of genes from the mitochondrial to the nuclear genome, the genetic control of most of the mechanisms described above pass to the nucleus. However, certain toxin precursors or metabolic pathways causing the production of toxins still locate to the mitochondrion. 
destruction of the plasmid by a bacterium that has commenced its transcription will kill the bacterial host. Failure to transcribe the antidote-encoding gene would cause depletion of the short-lived life-saving molecule before the toxin disappears. This mechanism has been proposed to be at the origin of bacterial 'programmed cell death' (Yarmolinsky, 1995). A similar mechanism could be involved in the generation of endosymbiosis. Thus, the promitochondrion invading the ancestral eukaryote might have developed one or several 'addiction modules' to stabilize the host/parasite micro-ecosystem.

\section{The endosymbiont hypothesis of apoptosis: a speculative scenario}

Based on the above premises, it is conceivable that the basic mechanism of apoptosis became fixed during evolution in the very moment in which endosymbiosis became established. Speculatively, invading aerobic bacteria may have employed suitable combinations of relatively stable toxins and labile antitoxins ('addiction modules') in order to become indispensable for the host (Figure 4A). Alternatively or in addition, such bacteria also contained pre-formed host-specific toxins so that bacterial lysis would kill the host cell (Figure 4B). This implies that bactericidal enzymes (e.g. specific proteases) produced by the host cell have to remain inactive, either by maintaining them as immature precursors or by sequestering them in subcellular compartments (e.g. lysosomes) well separated from the intruding bacterium (Figure 4C).

In this speculative scenario, a stable equilibrium based on mutual dissuasion would establish between the host and its invader. Any attempt of the pro-mitochondrion to kill the host and vice versa would be fatal for both partners, which thus have been trapped into symbiosis (Figure 4D, E). From this moment, the two initially independent organisms are forced to co-evolve. During this co-evolution, large parts of the bacterial genome are gradually incorporated into the nuclear genome (Figure 4F). This explains why murine cells from which the mitochondrial DNA has been depleted (and which thus possess mitochondria lacking DNA) can survive in special culture media and still can be induced to undergo apoptosis (Jacobson et al, 1993; Marchetti et al, 1996c,d). However, many of the apoptosis-controlling proteins encoded by nuclear genes continue to be imported into mitochondria (ANT, PBR, porin, cytochrome $c$ etc). or to act on mitochondrial membranes (Bcl-2 and homologues).

It is posible that mitochondrial PT has evolved together with or shortly after the establishment of endosymbiosis (Figure 5). As discussed above, cyclophilin, porin/VDAClike molecules, PBR-like molecules, and even structural $\mathrm{Bcl}-2$ homologues (the colicins and diphteria toxin) are found in certain bacteria. In this context, it is intriguing that porin-like molecules may fulfil an essential role for endosymbiosis, as suggested by the fact that only porin B-expressing Neisseria can accommodate as intracellular pathogens in epithelial cells. Incorporation of such a Neisseria porin into the host phagosome membrane surrounding phagocytosed Neisseria is essential for intracellular parasitism, possibly due to porin's function as an ATP sensor (Rudel et al, 1996). It is conceivable that during the redistribution of such molecules from bacterial to host membranes, for instance during the transposition of porin from the outer bacterial membrane to host membranes, the basic PT pore became established. As an alternative, the PT pore may have arisen when the ANT evolved after the initial stage of endosymbiosis (Walker and Runswick, 1993). Intriguingly, the ANT plays a major role in the distribution of ATP between hosts and intracellular parasites in another system (Plasmodium falciparum in human erythrocytes) (Kanaani and Ginsburg, 1989). The essential role of the PT pore (or of its components) in the host-parastie coordination, for instance at the level of ATP metabolism or respiratory control, would then account for the fixation of PT throughout eukaryotic evolution. In other words, the interaction of a few proteins at the host/parasite interface would be neuralgic for endosymbiosis but would also lay the evolutionary grounds of apoptotic cell death. Some apoptosis effector molecules with essential metabolic functions (cytochrome $c$ and perhaps proteases) were already present in the precursor of the mitochondrion. The release of these molecules would then become subordinated to PT, thereby connecting PT to the
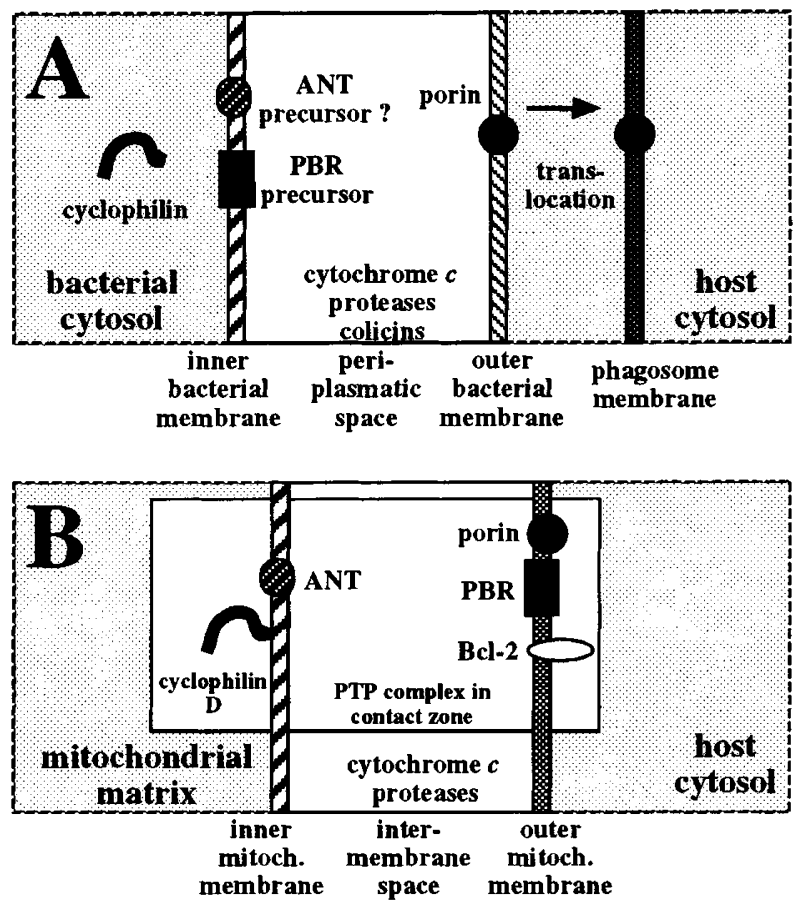

Figure 5 Highly speculative model for the molecular evolution of mitochondrial permeability transition (PT). (A) Hypothetical state of the PT pore precursor in the moment of bacterial pathogen accommodation. An aerobic bacterium possessing two membranes (inner + outer membrane) is surrounded by a phagosome membrane of the eukaryotic host cell. During this step, certain molecules e.g. porins translocate from bacterial to host membranes and assure the diffusion of small molecules (including ATP) at the host-parasite interface. (B) Later during evolution, the ANT arises in its mature form, allowing for the formation of the PT pore complex (within the white rectangle). Note that only few changes are necessary to evolve from $\mathbf{A}$ to B. Within the intermembrane space of bacteria and mitochondria potentially toxic molecules including cytochrome $c$ and certain proteases are present. The PT-dependent release of such molecules may be ultimately responsible for apoptosis. 
activation of proteases which degrade vital proteins and give rise to the apoptotic phenotype.

The endosymbiont hypothesis of apoptosis would explain why this mode of cell death already exists in unicellular eukaryotes, in which the existence of PCD obviously cannot constitute a direct advantage for Darwinian selection. In this context it should be mentioned that apoptosis induced in unicellular eukaryotes is only observed in response to non-physiological (non-receptormediated) triggers such as irradiation, antibiotics, complement or suboptimal culture conditions (Ameisen et al, 1995; Scheuerlein et al, 1995; Moreira et al, 1996; Mpoke and Wolfe, 1996; Welburn et al, 1996). It is plausible that regulated apoptosis (programmed cell death) has developed concomitantly with multicellularity, when PT control becomes connected with signal transduction pathways.

In addition to its heuristic value, the endosymbiont theory of apoptosis allows for the formulation of a series of testable hypotheses. Thus for instance, primitive unicellular eukaryotes still lacking mitochondria (e.g. Giardia intestinalis) should lack apoptosis-like phenomena. Moreover, apoptosis-like death of cells from plants and fungi should be associated with mitochondrial alterations early during the death process. Future studies will unravel these incognita.

\section{Conclusions}

Although apoptosis has been commonly described as a nuclear process, it now appears that mitochondrial permeability transition (PT) is the (or one of the) mechanisms which 'decides' between death and life. PT fulfils most if not all criteria that must be met by the central executioner of apoptosis: (i) PT is an early event of the apoptotic cascade; (ii) it is sufficient and necessary for the induction of apoptosis; (iii) it is induced by many different endogenous effectors and apoptosis induction protocols; (iv) its inhibition by specific drugs or $\mathrm{Bcl}-2$ hyperexpression is sufficient to prevent all downstream manifestations of apoptosis; (v) it functions in all mammalian cell types; (vi) it may be vital for normal metabolism; and (vii) it has self-amplifying properties and thus responds in an all-or-nothing fashion.

PT has at least three lethal consequences: (i) it causes the liberation of apoptogenic proteases and protease activators from the mitochondrial intermembrane space into the cytosol; (ii) it entails the hyperproduction of superoxide anions from the uncoupled respiratory chain and thus causes a severe, irreversible derangement of the redox potential; and (iii) it provokes the depletion of energyrich phosphates (NAD(P) $\mathrm{H}_{2}$ and $\left.A T P\right)$. PT is not only essential for apoptotic cell death; its involvement in certain models of necrosis has been documented. It is possible that the pace at which PT is induced, as well as the availability of apoptogenic proteases and/or their substrates may decide the mode of cell death. The metabolic consequences of PT cause necrosis unless proteases come into action. Whenever PT is induced in a fulminant fashion and/or the energy metabolism is severely compromised, the bioenergetic and redox catastrophe following PT causes necrotic cell death before apoptosis can occur. This scenario would weaken the opposition between apoptosis and necrosis and explain how $\mathrm{Bcl}-2$, which functions as an inhibitor of PT, can prevent both apoptosis and, at least in some systems, necrosis.

The mitochondrial control of apoptosis may have farreaching implications for the evolution of cell death. It appears plausible that apoptosis arose as a by-product of endosymbiosis in unicellular eukaryotes before multicellularity developed.

\section{Acknowledgements}

I would like to thank my colleagues Drs Castedo, Brunner, Dallaporta, Decaudin, Marchetti, Marzo, Petit, Susin, Zamzami (CNRS, Villejuif, France) for helpful discussion. Special thanks to Drs Pierre Golstein and Jean-Claude Ameisen for passionate discussion of apoptosis evolution. Supported by Agence Nationale pour la Recherche sur le SIDA, Association pour la Recherche contre le Cancer, Centre Nationale de la Recherche Scientifique, Fondation de France, Fondation pour la Recherche Médicale, Leo Foundation, Ligue Française contre le Cancer, Institut National de la Santé et de la Recherche Médicale, NATO, Sidaction and the French Ministry of Science.

\section{References}

Aguilar HI, Botla R, Arora AS, Bronk SF and Gores GJ (1996) Induction of the mitochondrial permeability transition by protease activity in rats: A mechanism of hepatocyte necrosis. Gastroenterology 110: 558-566

Ameisen JC, Idziorek T, Billaut-Mulot O, Loyens M, Tissier JP, Potentier A and Ouiassi A (1995) Apoptosis in an unicellular eukaryote (Trypanosoma cruzi): Implications for the evolutionary origin and role of programmed cell death in the control of cell proliferation, differentiation and survival. Cell Death Differ. 2:285300

Ankarcrona M, Dypbukt JM, Bonfoco E, Zhivotovsky B, Orrenius S, Lipton SA and Nicotera P (1995) Glutamate-induced neuronal death: a succession of necrosis or apoptosis depending on mitochondrial function. Neuron 15: 961-973

Armstrong GA, Alberti M, Leach F and Hearst JE (1989) Nucleotide sequence, organization and nature of the protein products of the carotenoid biosynthesis gene cluster of Rhodobacter capsulatus. Mol. Gen. Genet. 216: 254-268

Barr PJ and Tomei LD (1994) Apoptosis and its role in human disease. Biotechnology 12: $487-493$

Bernardi P (1992) Modulation of the mitochondrial cyclosporin A-sensitive permeability transition pore by the proton electrochemical gradient. J. Biol. Chem. 267: 8834-8839

Bernardi P and Petronilli V (1996) The permeability transition pore as a mitochondrial calcium release channel; a critical appraisal. J. Bioenerg. Biomembr. 28: 129136

Bernardi P, Vassanelli S, Veronese P, Colonna R, Szabò I and Zoratti M (1992) Modulation of the mitochondrial permeability transition pore. Effect of protons and divalent cations. J. Biol. Chem. 267: 2934-2939

Beutner G, Rück A, Riede B, Welte W and Brdiczka D (1996) Complexes between kinases, mitochondrial porin, and adenylate translocator in ratbrain resemble the permeability transition pore. FEBS Lett. 396: 189-195

Brustovetsky N and Klingenberg M (1996) Mitochondrial ADP/ATP carrier can be reversibly converted into a large channel by $\mathrm{Ca} 2+$. Biochemistry $35: 8483-8488$

Cain K, Inayathussain SH, Couet C and Cohen GM (1996) A cleavage-sitedirected inhibitor of interleukin 1-beta-converting enzyme-like proteases inhibits apoptosis in primary cultures of rat hepatocytes. Biochem. J. 314: $27-32$

Carmeli C and Lifshitz Y (1989) Nucleotide transpôrt in Rhodbacter capsulatus. J. Bacteriol. 171: 6521-6525

Castedo M, Hirsch T, Susin SA, Zamzami N, Marchetti P, Macho A and Kroemer G (1996) Sequential acquisition of mitochondrial and plasma membrane alterations during early lymphocyte apoptosis. J. Immunol. 157: 512-521 
Castedo M, Macho A, Zamzami N, Hirsch T, Marchetti P, Uriel Jand Kroemer G (1995) Mitochondrial perturbations define lymphocytes undergoing apoptotic deplection in vivo. Eur. J. Immunol. 25: 3277-3284

Cohen JJ (1991) Programme cell death in the immune system. Adv. Immunol. 50: $55-85$

Cornillon S, Foa C, Davoust J, Buonavista N, Gross JD and Golstein P (1994) Programmed cell death in Dictiostelium. J. Cell Science 107: 2691-2704

Cossarizza A, Franceschi C, Monti D, Salvioli S, Bellesia E, Rivabene R, Biondo L, Rainaldi G, Tinari A and Malorni W (1995) Protective effect of N-acetylcysteine in tumor necrosis factor-alpha-induced apoptosis in U937 cells: the role of mitochondria. Exp. Cell Res. 220: 232-240

Constantini P, Chernyak BV, Petronilli V and Bernardi P (1996) Modulation of the mitochondrial permeability transition pore by pyridine nucleotides and dithiol oxidation at two separate sites. J. Biol. Chem. 271: 6746-6751

Decaudin D, Geley S, Hirsdch T, Castedo M, Marchetti P, Macho A, Kofler R and Kroemer G (1997) Bcl-2 and Bcl-XL antagonize the mitochondrial dysfunction preceding nuclear apoptosis induced by chemotherapeutic agents. Cancer Res. 57: $62-67$

Deckwerth TL and Johnson EM (1993) Temporal analysis of events associated with programmed cell death (apoptosis) of sympathetic neurons deprived of nerve growth factor. J. Cell Biol. 123: 1207-1222

Evtodienki YV, Teplova VV, Sidashi SS, Ichas F and Mazat J-P (1996) Microtubuleactive drugs suppress the closure of the permeability transition pore in tumour mitochondria. FEBS Lett. 393: 86-88

Fearnhead HO, Dinsdale D and Cohen GM (1995) An interleukin-1 beta-converting enzyme-like protease is a common mediator of apoptosis in thymocytes. FEBS Lett. 375: $283-288$

Fiskum G and Murphy AN (1996) Bcl-2 protects mitochondria from Ca2+ induced respiratory inhibition and release of cytochrome $c$ (Abstract). Mol. Biol. Cell 7: $33 \mathrm{~A}$

Fliss Hand GattingerD (1996) Apoptosis in ischemic and reperfused rat myocardium. Circulation Res. 79: 949-956

Gonzalez-Garcia M, Perez-Ballestero R, Ding LY, Duan L, Boise LH, Thompson CB and Nuñez G (1994) Bcl-xL is the major bcl-x mRNA form expressed during murine development and its product localizes to mitochondria. Development 120: $3033-3042$

Gray MW (1989) Origin and evolution of mitochondrial DNA. Annu. Rev. Biochem. 5: $25-50$

Greenberg JT (1996) Programmed cell death: A way of life for plants. Proc. Natl. Acad. Sci. USA 93: 12094-12097

Greenhalf W, Stephan C and Chaudhuri B (1996) Role of mitochondria and Cterminal membrane anchor of $\mathrm{Bcl}-2$ in Bax induced growth arrest and mortality in Sacharomyces cerevisiae. FEBS Lett. 380: 169-175

Hengartner MO and Horvitz HR (1994) C. elegans cell survival gene ced-9 encodes a functional homolog of the mammalian proto-oncogene bcl-2. Cell 76: 665-676

Henkart PA (1995) Apoptosis: O death, where is thy sting? J. Immunol. 154: $4905-$ 4908

Henkart PA (1996) ICE family proteases: Mediators of all apoptotic cell death? Immunity 4: 195-201

Hug $\mathrm{H}$, Enari $M$ and Nagata S (1994) No requirement of reactive oxygen intermediates in Fas-mediated apoptosis. FEBS Lett. 351: 311-313

Igbavboa U, Zwizinski CW and Pfeiffer DR (1989) Release of mitochondrial matrix proteins through a $\mathrm{Ca2+-requiring,} \mathrm{cyclosporin-sensitive} \mathrm{pathway.} \mathrm{Biochem.}$ Biophys. Res. Comm. 161: 619-625

Ishizaki Y, Cheng L, Mudge AW and Raff MC (1995) Programmed cell death by default in embryonic cells, fibroblasts, and cancer cells. Mol. Biol. Cell (1995) 1443-1458

Itoh G, Tamura J, Suzuki M, Suzuki Y, Ikeda H, Koike M, Nomura M, Jie T and Ito K (1995) DNA fragmentation of human infarcted myocardial cells demonstrated by the nick end labeling method and DNA agarose gel electrophoresis. Am. J. Pathol. 146: 1325-1331

Jacobson MD, Burne JF, King MP, Miyashita T, Reed JC and Raff MC (1993) Bcl-2 blocks apoptosis in cells lacking mitochondrial DNA. Nature 361: $365-369$

Jacobson MD, Burne JF and Raff MC (1994) Programmed cell death and Bcl-2 protection in the absence of a nucleus. EMBO J. 13: 1899-1910

Jacobson MD and Raff MC (1995) Programmed cell death and Bcl-2 protection in very low oxygen. Nature $374: 814-816$
Jacobson MD, Weil M and Raff MC (1996) Role of Ced-3/ICE-family proteases in staurosporine-induced programmed cell death. J. Cell Biol. 133: $1041-$ 1051

Jensen RB and Gerdes K (1995) Programmed cell death in bacteria: proteic plasmid stabilization systems. Mol. Microbiol. 17: 205-210

Jones AM and Dangl JL (1996) Logjam at the Styx: Programmed cell death in plants. Trends in Plant Science 1: 114-119

Kanaani J and Ginsburg H (1989) Metabolic interconnection between the human malarial parasite Plasmodium falciparum and its host erythrocyte regulation of ATP levels by means of an adenylate translocator and adenylate kinase. J. Biol. Chem. 264: 3194-3199

Kane DJ, Sarafian TA, Anton R, Hahn H, Gralla EB, Valentine JS, Örd T and Bredesen DE (1993) Bcl-2 inhibition of neural death: decreased generation of reactive oxygen species. Science 262: 1274-1277

Kerr JFR, Wyllie AH and Currie AR (1972) Apoptosis: a basic biological phenomenon with wide-ranging implications in tissue kinetics. Br. J. Cancer 26: $239-257$

Kinnally KW, Lohret TA, Campo ML and Mannella CA (1996) Perspectives on the mitochondrial multiple conductance channel. J. Bioenerg. Biomembr. 28: 115123

Kinnally KW, Zorov DB, Antonenko YN, Snyder SH, McEnergy MW and Tedeschi H (1993) Mitochondrial benzodiazepine receptor linked to inner membrane ion channels by nanomolar actions of ligands. Proc. Natl. Acad. Sci. USA 90: 1374 1378

Klingenberg M (1980) The ADP-ATP translocation in mitochondria, a membrane potential controlled transport. J. Membrane Biol. 56: 97-105

Kluck RM, Bossy-Wetzel E, Green DR and Newmeyer DD (1997) The release of cytochrome $\mathrm{c}$ from mitochondria: a primary site for $\mathrm{Bcl}-2$ regulation of apoptosis. Science 275: $1132-1136$

Knudson CM, Tung KS, Tourtellotte WG, Brown GA and Korsmeyer SJ (1995) Baxdeficient mice with lymphoid hyperplasia and male germ cell death. Science 270 : 96-99

Krajewski S, Tanaka S, Takayama S, Schibler MJ, Fenton W and Reed JC (1993) Investigation of the subcellular distribution of the bcl-2 oncoprotein: residence in the nuclear envelope, endoplasmic reticulum, and outer mitochondrial membranes. Cancer Res. 53: 4701-4714

Krause DC, Winkler HH and Wood DO (1985) Cloning and expression of the Rickettsia prowazekii ADP/ATP translocator in E. coli. Proc. Natl. Acad. Sci. USA 82: $3015-3019$

Krippner A, Matsuno-Yagi A, Gottlieb RA and Babior BM (1996) Loss of function of cytochrome $c$ in Jurkat cells undergoing Fas-mediated apoptosis. J. Biol. Chem. 271: $21629-21636$

Kroemer G (1995) The pharmacology of T cell apoptosis. Adv. Immunol. 58: 211 296

Kroemer G, Petit PX, Zamzami N, Vayssière J-L and Mignotte B (1995) The biochemistry of apoptosis. FASEB J. 9: 1277-1287

Kroemer G, Zamzami N and Susin SA (1997) Mitochondrial control of apoptosis. Immunol. Today 18: $44-51$

Kuan J and Saier MHJ (1993) The mitochondrial carrier family of tansport proteins: structural, functional, and evolutionary relationships. Crit. Rev. Biochem. Mol. Biol. 28: 209-233

Liu X, Kim CN, Yang J, Jemmerson R and Wang X (1996) Induction of apoptotic program in cell-free extracts: requirement for dATP and cytochrome C. Cell 86: $147-157$

Macho A, Decaudin D, Castedo M, Hirsch T, Susin SA, Zamzami N and Kroemer G (1996) Chloromethyl-X-rosamine is an aldehyde-fixable potential-sensitive fluorochrome for the detection of early apoptosis. Cytometry 25: $333-340$

Macho A, Hirsch T, Marzo I, Marchetti P, Dallaporta B, Susin SA, Zamzami N and Kroemer G (1997) Glutathione depletion is an early and calcium elevation a late event of thymocyte apoptosis. J. Immunol in press

Marchetti P, Castedo M, Susin SA, Zamzami N, Hirsch T, Haeffner A, Hirsch F, Geuskens M and Kroemer G (1996a) Mitochondrial permeability transition is a central coordinating event of apoptosis. J. Exp. Med. 184: $1155-1160$

Marchetti P, Decaudin D, Macho A, Zamzami N, Hirsch T, Susin SA and Kroemer G (1997) Redox regulation of apoptosis: impact of thiol redoxidation on mitochondrial function. Eur. J. Immunol. 27: 289-296 
Marchetti P, Hirsch T, Zamzami N, Castedo M, Decaudin D, Susin SA, Masse B and Kroemer G (1996b) Mitochondrial permeability transition triggers lymphocyte apoptosis. J. Immunol. 157: 4830-4836

Marchetti P, Susin SA, Decaudin D, Gamen S, Castedo M, Hirsch T, Zamzami N, Naval J. Senik A and Kroemer G (1996c) Apoptosis-associated derangement of mitochondrial function in cells lacking mitochondrial DNA. Cancer Res. 56: 2033-2038

Marchetti P, Zamzami N, Susin SA, Patrice PX and Kroemer G (1996d) Apoptosis of cells lacking mitochondrial DNA. Apoptosis 1: 119-125

Margulis L (1975) Symbiotic theory of the origin of eukaryotic organelles. Symbiosis (DH Jenning \& DL Leed eds.) Symposium 29: Society for Experimental Biology pp 21 - 38. Cambridge University Press, Cambridge

Martin SJ and Green DR (1995) Protease activation during apoptosis: death by a thousand cuts? Cell 82: 349-352

Martinou JC, Dubois-Dauphin-M, Staple JK, Rodriguez I, FrankowskiH, Missotten M, Albertini P, Talabot D, Catsikas S, Pietra C and Huarte J (1994) Overexpression of $\mathrm{Bcl}-2$ in transgenic mice protects neurons from naturally occurring cell death and experimental ischemia. Neuron 13: 1017-1030

McCarthy NJ, Whyte MKB, Gilbert CS and Evan GI (1997) Inhibition of Ced-e/ICErelated proteases does not prevent cell death induced by oncogenes, DNA damage, or the Bcl-2 homologue Bak. J. Cell Biol. 136: 215-227

McEnergy MW, Snowman AM, Trifiletti RR and Snyder SH (1992) Isolation of the mitochondrial benzodiazepine receptor: Association with the voltage-dependent anion channel and the adenine nucleotide carrier. Proc. Natl. Acad. Sci. USA 89: $3170-3174$

Mittler R and Lal E (1995) In situ detection of nDNA fragmentation during the differentiation of tracheary elements in higher plants. Plant Physiol. 108: 489 493

Moreira MEC, Delportillo HA, Milder RV, Balanco JMF and Barcinski MA (1996) Heat shock induction of apoptosis in promastigotes of the unicellular organism Leishmania (Leishmania) amazonensis. J. Cell Physiol. 167: 305-313

Mpoke S and Wolfe J (1996) DNA digestion and chromatin condensation during nuclear death in Tetrahymena. Exp. Cell Res. 225: 357-365

Muchmore SW, Sattler M, Liang H, Meadows RP, Harlan JE, Yoon HS, Nettesheim D, Chang BS, Thompson CB, Wong S-L, Ng S-H and Fesik SW (1996) X-ray and NMR structure of human $\mathrm{Bcl}-\mathrm{xL}$, and inhibitor of programmed cell death. Nature 381: $335-341$

Murphy AN, Bredesen DE, Cortopassi G, Wang E and Fiskum G (1996) Bcl-2 potentiates the maximal calcium uptake capacity of neural cell mitochondria. Proc. Natl. Acad. Sci. USA 93: 9893-9898

Naito T, Kusano Kand Kobayashi I (1995) Selfish behavior of restriction-modification systems. Science 267: 897-899

Nakajima H, Golstein P and Henkart PA (1995) The target cell nucleus is not required for cell-mediated granzyme- or Fas-based cytotoxicity. J. Exp. Med. 181: 19051909

NewmeyerDD, Farschon DM and Reed JC (1994)Cell-free apoptosis in xenopus egg extracts: inhibition by $\mathrm{Bcl}-2$ and requirement for an organelle fraction enriched in mitochondria. Cell 79: 353-364

Nguyen M, Branton PE, Walton PA, Oltvai ZN, Korsmeyer SJ and Shore GC (1994) Role of membrane anchor domain of $\mathrm{Bcl}-2$ in suppression of apoptosis caused by E1B-defective adenovirus. J. Biol. Chem. 269: 16521 - 16524

Nicholson DW, All A, Thornberry NA, Vaillancourt JP, Ding CK, Gallant M, Gareau Y, Griffin PR, Labelle M, Lazebnik YA, Munday NA, Raju SM, Smulson ME, Yamin TT, Yu VM and Miller DK (1995) Identification and inhibition of the ICE/CED-3 protease necessary for mammalian apoptosis. Nature $376: 37-43$

Nicolli A, Basso E, Petronilli V, Wenger RM and Bernardi P (1996) Interactions of cyclophilin with mitochondrial inner membrane and regulation of the permeability transition pore, a cyclosporin A-sensitive channel. J. Biol. Chem. 271: 21852192

Nicotera P and Leist M (1997) Energy supply and the shape of death in neurons and lymphoid cells. Cell Death Differ. 4: 435-442

Oltvai ZN and Korsmeyer SJ (1994) Checkpoints of dueling dimers foil death wishes. Cell $79 \cdot 189-192$

Pastorino JG, Simbula G, Gilfor E, Hoek JB and Farber JL (1994) Protoporphyrin IX, an endogenous ligand of the peripheral benzodiazepin receptor, potentiates induction of the mitochondrial permeability transition and the killing of culture hepatocytes by rotenone. J. Biol. Chem. 269: 31041-31046
Petit PX, LeCoeur H, Zorn E, Dauguet C, Mignotte B and Gougeon ML (1995) Alterations of mitochondrial structure and function are early events of dexamethasone-induced thymocyte apoptosis. J. Cell Biol. 130: 157-167

Petit PX, Susin SA, Zamzami N, Mignotte B and Kroemer G (1996) Apoptosis and mitochondria: back to the future. FEBS Lett. 396: 7-14

Pfeiffer DR, Gudz TI, Novgorodov SA and ErdahI WL (1995) The peptide mastoparan is a potent facilitator of the mitochondrial permeability transition. J. Biol. Chem. 270: 4923-4932

Polla BS, Kantengwa S, Francois D, Salvioli S, Franceschi C, Marsac C and Cossarizza A (1996) Mitochondria are selective targets for the protective effects of heat shock against oxidative injury. Proc. Nat. Acad. Sci. USA 93: 6458-6463

Ptashne M, Jeffery A and Johnson AD (1980) How the lambda repressor and Cro work. Cell 19: 1-11

Raff M (1994) Social control of cell survival and cell death. Nature 365: 397-400

Rawlings ND and Barrett (1993) Evolutionary families of peptidases. Biochem. J. 290: $205-218$

Rostovtseva T and Colombini M (1996) ATP flux is controlled by a voltage-gated channel from the mitochondrial outer membrane. J. Biol. Chem. 271: 2800628008

Rudel T, Schmid A, Benz R, Kolb H-A, Lang F and Meyer TF (1996) Modulation of Neisseria porin (porB) by cytosolic ATP. GTP of target cells: parallels between pathogen accommodation and mitochondrial endosymbiosis. Cell 85: 391-402

Sasaki H, Matsuno T, Tanaka N and Orita K (1996) Activation of apoptosis during the reperfusion phase after rat liver ischemia. Tranpl. Proc. 28: 1908-1909

Sato T, Hanada M, Bodrug S, Irie S, Iwama N, Boise LH, Thompson CB, Golemis E Fong L, Wang H-G and Reed JC (1994) Interactions among members of the Bcl-2 protein family analyzed with a yeast two-hybrid system. Proc. Natl. Acad. Sci. 91: $9238-9242$

Scheuerlein R, TremIS, TharB, Tirlapur UK and HaderDP (1995) Evidence for UV-B induced DNA degradation in Euglena gracilis mediated by activation of metaldependent nucleases. J. Photochem. Photobiol. B. Biol 31: 113-123

Schinder AF, Olson EC, Spitzer NC and Montal M (1996) Mitochondrial dysfunction is a primary event in glutamate neurotoxicity. Journal of Neuroscience 16:61256133

Schulz GE (1996) Porins: general to specific, native to engineered passive pores Curr. Op. Struct. Biol. 6: 485-490

Schulze-Osthoff K, Walczak H, Droge W and Krammer PH (1994) Cell nucleus and DNA fragmentation are not required for apoptosis. J. Cell Biol. 127 $15-20$

Scott MP and O'Farrel PH (1986) Spatial programming of gene expression in early Drosophila embryogenesis. Annu. Rev. Cell Biol. 2: 49-80

Shimizu S, Eguchi Y, Kamiike W, Waguri S, Uchiyama Y, Matsuda H and Tsujimoto Y (1996) Bcl-2 blocks loss of mitochondrial membrane potential while ICE inhibitors act at a different step during inhibition of death induced by respiratory chain inhibitors. Oncogene 13: 21-29

Shimizu S, Eguchi Y, Kosaka H, Kamlike W, Matsuda H and Tsujimoto Y (1995) Prevention of hypoxia-induced cell death by Bcl-2 and Bcl-xL. Nature 374:811 813

Simonian NA, Getz RL, Leveque JC, Konradi C and Coyle JT (1996) Kainate induces apoptosis in neurons. Neuroscience 74: 675-683

Slee EA, Zhu HJ, Chow SC, Macfarlane M, Nicholson DW and Cohen GM (1996) Benzyloxycarbonyl-Val-Ala-Asp (OMe) fluoromethylketone (Z-VAD.fmk) inhibits apoptosis by blocking the processing of CPP32. Biochem. J. 315: 21-24

Sokolove PM and Kinnally KW (1996) A mitochondrial signal peptide from Neurospora crassa increases the permeability of isolated rat liver mitochondria. Arch. Biochem. Biophysics 336: 69-76

Stroud R (1995) lon channel forming colicins. Curr. Op. Struct. Biol. 5: 514-520

Susin SA, Zamzami N, Castedo M, Hirsch T, Marchetti P, Macho A, Daugas E, Geuskens M and Kroemer G (1996a) Bcl-2 inhibits the mitochondrial release of an apoptogenic protease. J. Exp. Med. 184: 1331-1342

Susin SA, Zamzami N and Kroemer G (1996b) The Cell Biology of apoptisis: evidence for the involvement of mitochondria. Apoptosis 1: 231-242

Szabo I, Bathori G, Wolff D, Starc T, Cola C and Zoratti M (1995) The highconductance channel of porin-less yeast mitochondria. Biochem. Biophys. Acta Biomembranes 1235: 115-125

Szabó I, Bernardi P and Zoratti M (1992) Modulation of the mitochondrial megachannel by divalent cations and protons. J. Biol. Chem. 267: 2940-2946 
Tanaka S, Saito K and Reed JC (1993) Structure-function analysis of the Bcl-2 oncoprotein. Addition of a heterologous transmembrane domain to portions of the $\mathrm{Bcl}-2 \beta$ protein restores function as a regulator of cell survival. J. Biol. Chem. 268: $10920-10926$

Thompson CB (1995) Apoptosis in the pathogenesis and treatment of disease. Science 267: $1456-1462$

Trost LC and Lemasters JJ (1996) The mitochondrial permeability transition: A new pathophysiological mechanism for Reye's syndrome and toxic liver injury. J. Pharmacol. Exp. Ther. 278: 1000-1005

Tsujimoto Y (1997) Apoptosis and necrosis: intracellular ATP levels as a determinant for cell death modes. Cell Death Differ. 4: 429-434

Vayssière J-L, Petit PX, Risler Y and Mignotte B (1994) Commitment to apoptosis is associated with changes in mitochondrial biogenesis and activity in cell lines conditionally immortalized with simian virus 40 . Proc. Natl. Acad. Sci. USA 91: $11752-11756$

Walker JE and Runswick MJ (1993) The mitochondrial transport protein superfamily. J. Bioenerg. Biomembr. 25: 435-446

Weil M, Jacobson MD, Coles HSR, Davies TJ, Gardner RL, Raff KD and Raff MC (1996) Constitutive expression of the machinery for programmed cell death. J. Cell Biol. 133: 1053-1059

Welburn SC, Dale C, Ellis D, Beecroft R and Pearson TW (1996) Apoptosis in procyclic Trypanosoma brucei rhodesiense in vitro. Cell Death Diff. 3: 229-236

Wertz IE and Hanley MR (1996) Diverse molecular provocation of programmed cell death. Trends Biochem. Sci. 21: 359-364

White RJ and Reynolds IJ (1996) Mitochondrial depolarization in glutamatestimulated neurons: An early signal specific to excitotoxin exposure. Journal of Neuroscience 16: 5688-5697

Xiang J, Chao DT and Korsmeyer SJ (1996) Bax-induced cell death may not require interleukin 1beta-converting enzyme-like proteases. Proc. Natl. Acad. Sci. USA 93: $14559-14563$
Yang J, Liu X, Bhalla K, Kim CN, Ibrado AM, Cai J, Peng T-I, Jones DP and Wang X (1997) Prevention of apoptosis by Bcl-2: release of cytochrome c from mitochondria blocked. Science 275: 1129-1132

Yarmolinsky MB (1995) Programmed cell death in bacterial populations. Science 267: $836-837$

Zamzami N, Marchetti P, Castedo M, Decaudin D, Macho A, Hirsch T, Susin SA, Petit PX, Mignotte B and Kroemer G (1995a) Sequential reduction of mitochondrial transmembrane potential and generation of reactive oxygen species in early programmed cell death. J. Exp. Med. 182: 367-377

Zamzami N, Marchetti P, Castedo M, Hirsch T, Susin SA, Masse B and Kroemer G (1996a) Inhibitors of permeability transition interefere with the disruption of the mitochondrial transmembrane potential during apoptosis. FEBS Lett. 384: 53-

Zamzami N, Marchetti P, Castedo M, Zanin C, Vayssière J-L, Petit PX and Kroemer G (1995b) Reduction in mitochondrial potential constitutes an early irreversible step of programmed lymphocyte death in vivo. J. Exp. Med. 181: 1661-1672

Zamzami N, Susin SA, Marchetti P, Hirsch T, Gómez-Monterrey I, Castedo M and Kroemer G (1996b) Mitochondrial control of nuclear apoptosis. J. Exp. Med. 183: $1533-1544$

Zha H, Fisk HA, Yaffe MP, Mahajan N, Herman B and Reed JC (1996) Structurefunction comparisons of the pro-apoptotic protein Bax in yeast and mammalian cells. Mol. Cell. Biol. 16: 6494-6508

Zhu HJ, Fearnhead HO and Cohen GM (1995) An ICE-like protease is a common mediator of apoptosis induced by diverse stimuli in human monocytic THP.1 cells. FEBS Lett. 374: 303-308

Zhu W, Cowie A, Wasfy GW, Penn LZ, LeberBand Andrews DW (1996) Bcl-2 mutants with restricted subcellular localization reveal spatially distinct pathways for apoptosis in different cell types. EMBO J. 15: 4130-4141

Zoratti M and Szabò I (1995) The mitochondrial permeability transition. Biochem. Biophys. Acta-Rev. Biomembranes 1241: 139-176 